\title{
ТАНЕЦЬ ЯК СИСТЕМА: СПРОБА СЕМІОТИЧНОГО АНАЛІЗУ
}

У статті здійснено семіотичний аналіз хореографічного мистецтвва, виявлено специфріку знаків та символів як основних компонентів танцювальної мови, звернено увагу на специфічну відмінність знаків у мистецтві та символізм - як вищий прояв образного танцювального мистецтва. Танець розглянутий як хранитель тієї культурно значущої інформаџїі, яка сягає свойм корінням у глибину століть i в наступні епохи виступає як символи. Зроблено висновок, щь для розгляду танцювального мистецтва як знакової системи потрібно, насамперед, досліджувати особливості його участі в процесі семіозису - прочесу, в якому щось функціонує як знак. Це дасть можливість відкрити об 'єктивні інформаційні комунікативні властивості рухів танцю і виявити в них якості специфічної мови.

Ключові слова: танець, символ, знак, образ, семіотика, семіозис.

В статье осуществлен семиотический анализ хореографического искусства, выявлена специиика знаков и символов в качестве основных компонентов танцевального языка, обращено внимание на специфическое отличие знаков в искусстве и символизм - как высшее проявление образного танцевального искусства. Танеи рассмотрен в качестве хранителя той культурно значимой информации, которая уходит своими корнями в глубину веков, и в последующие эпохи выступает в качестве символов. Сделан вывод, что для рассмотрения танцевального искусства как знаковой системы необходимо, в первую очередь, исследовать особенности его участия в прочессе семиозиса - процесса, в котором что-то функционирует как знак. Это даст возможность открыть объективные информационные коммуникативные свойства движений танца и выявить в них качества спечифического языка.

Ключевые слова: танец, символ, знак, образ, семиотика, семиозис.

The article semiotic analysis choreography revealed the specific characters and symbols as a basic component of dance language, drawn attention to the specific distinction marks in art and symbolism as the highest expression of imaginative dance, dance is considered as the guardian of culturally significant information to its roots in ancient times, and in subsequent periods serving as symbols. It was concluded that to consider dance as a sign system is necessary, first, to explore the features of its participation in semiosis - the process in which something functions as a sign. This will open objective information communication properties dance movements and identify them as specific language.

Key words: dance, symbol, sign, image, semiotics, semiosis.

Із семантичної точки зору будь-який феномен культури має символічні властивості й тому може бути розглянутий як такий, що містить і виражає певну інформацію. Одним з таких феноменів $\epsilon$ танець, мистецтво якого завжди відігравало одну 3 провідних ролей у житті людини та в соціокультурному просторі. Без перебільшення можна стверджувати, що танцювальне мистецтво стало одним з визначальних явищ сучасності, явищем, що виступає своєрідним текстом, який відображає культуру народу, і є невіддільним від людини, оскільки народжується в іiі тілі. Більше того, танець відображає в собі всю культуру в її цілісності: зміни різних сфер культури зумовлюють зміни і в сфері танцю, про що свідчить його (танцю) проникнення у ті сфери культури, де раніше він не відігравав вирішальної ролі чи взагалі не був представлений. Мистецтво танцю створює для людини світ життєвих переживань, виражених специфічними образно-символічними засобами.

Сьогодні маємо велику кількість мистецтвознавчих праць 3 питань історії і техніки танцю, проте практично неопрацьованим залишається культурологічний підхід до його вивчення. До спроб виходу за межі мистецтвознавчого аналізу можна віднести нечисленні роздуми про танець $\mathrm{i}$ шляхи його розвитку видатних діячів танцювального мистецтва - А. Дункан, М. Бежара, С. Лифаря, I. Моїсеєва, В. Захарова та ін. Серед дослідників хореографічного мистецтва слід відзначити 
Л. Блок, Е. Корольову, Ю. Станішевського [18], Т. Чурпіту [21], Л. Цветкову [19] тощо. Крім того, людській тілесності як соціокультурному феномену присвячені дослідження І. Биховської [5], М. Мерло-Понті [12], М. Мосса [14], С. Леонової [9], М. Матвейчук [11], Н. Чілікіної [20] та ін. Слід відзначити й загальнотеоретичні праці з естетики та семіотики мистецтва М. Кагана, Ю. Лотмана, Г. В. Ф. Гегеля, Ч. Морріса, У. Еко, А. Моля, Є. Басіна [2] та інших, в яких автори стверджують, що для того, щоб сприйняти передану інформацію, потрібно володіти його (мистецтва) мовою.

Незважаючи на значну кількість праць, проблема образності танцю у культурологічному контексті чітко не сформульована, що й обумовлює потребу з'ясування сутності танцю як образно-знакової системи.

Метою статті $€$ вивчення танцю як образно-знакової системи, що дає змогу виявити специфіку танцювальної мови в аспекті іiі смислової змістовності.

Художня культура як елемент системи об'єктивізації соціокультурної діяльності передбачає матеріалізацію виробленої ідеальної предметності - знань, цінностей, проектів, образів. Такими засобами стають знакові системи - мови культури. Словесна мова $\epsilon$ не єдиною знаковою системою, що використовується для цієї мети духовним виробництвом і духовним спілкуванням людей, так само як і художньою творчістю. Безліч мов необхідні культурі тому, що іiї інформаційний зміст $\epsilon$ багатостороннім, багатим і кожен специфічний інформаційний процес потребує адекватних засобів втілення. У художній культурі основним засобом спілкування і комунікації людей $є$ найдавніша мова - невербальна. Вона стає самостійною мовою танцю і музики, входить до семіотичної сукупності складних мов сценічного мистецтва до творчості балетмейстера і танцівника.

У науковій літературі виокремлюють п'ять типів знакових систем: системи, побудовані на «природних знаках»; образні знакові системи; мовні системи; знакові системи запису і математико-формалізовані (кодові) знакові системи [17, 131-133]. Саме в такій послідовності, на думку ізраїльського вченого А. Б. Соломоника, ці системи кодування реального життя 3'являються в онтогенетичному розвитку людства і в філогенезі окремого індивідуума $[17,131]$. При цьому один тип знакових систем відрізняється від іншого головним чином характеристиками знака, який становить його основу. Саме такі знакові системи $є$ підгрунтям усіх мистецтв (крім літератури), в тому числі й танець.
Отже, образним знаковим системам передують природні, а знакам-образам - природні знаки. Під природним знаком розуміється предмет реального світу, який сам, будучи частиною цілого, свідчить про інші його частини і про їхній взаємозв'язок, тому слова це ще і не знаки, а радше їхня предтеча. Слідом за природним знаком, згідно з розробленою А. Соломоником ієрархією, йде образ, а слідом за природними знаковими системами - образні. Образ являє реальність принципово іншим шляхом, ніж природний знак. Це вже знак у повному розумінні слова: він заміщає інший предмет, представляючи і нагадуючи його, але не будучи при цьому його частиною. Він нагадує те, що позначається, але це вже знак чогось, а не сам предмет або його складова. I якщо при взаємодії з природними знаками людина не могла «відірватися» від реальності, то за наявності образів вона спроможна перенести реальність у сферу свідомості. Далі за образами з'являються мовні знаки, а потім і символи. Загалом ця ієрархія повністю має такий вигляд: природний знак вказує; образ - відображає; слово - описує; буква - фіксує; символ - кодує $[17,132]$.

Таким чином, мовний аспект передбачає, що танцювальний рух можна розглядати як знак. Так, рух тіла людини в реальному житті може виконувати роль природного знака, танцювальний рух це вже знак-образ, а танцювальне мистецтво образна знакова система. В історичному аспекті реальні рухи тіла людини поступово переходять у танцювальні, що і відкриває від початку властивий їм знаковий характер.

У хореографічному мистецтві текст танцю можна трактувати двояко: текст як знак і текст як певна сукупність знаків. Прийнято виокремлювати три групи знаків: 1) знаки-зображення (іконічні); 2) знаки-ознаки (симптоми, індекси, індексатори); 3) умовні знаки (символи) [6]. За аналогією елементи-знаки танцювальної мови також можна охарактеризувати і як знаки-зображення (статичні позиції і положення, система класичних рухів, вироблена в процесі історичного розвитку), і як знаки-ознаки (спонтанні, мимовільні виражальні рухи і жести), і як умовні знаки (жести, штучно розроблені рухи, контрольовані заданим емоційним станом - акторство в житті й на сцені). Будьяке позначення передбачає наявність мови, яким воно позначається. Знак, рух, па, поза, як система букв, самі по собі нічого не означають без осмислення, без вкладання в них позазнаковим носієм (танцюристом) певного смислу, ідеї, почуттів, настрою, стану [6]. 
Специфічну відмінність знаків у мистецтві Є. Я. Басін пояснює на прикладі іконічного знака: «... образотворчий знак у мистецтві - скажімо, портрет, скульптура і т.д. - призначений не лише передати інформацію про об'єкт, а й обов'язково сприяти тому, щоб у глядача виникло певне оцінювальне, емоційно забарвлене ставлення як до зображуваного, так і до самого образотворчого знака, причому ставлення до самого знака має бути відчуттям естетичного задоволення, властивість знаків викликати до себе позитивне естетичне ставлення $є$ тією необхідною додатковою вимогою, яка пред'являється до всіх знаків, що використовуються в мистецтві» [1]. Всі мистецтва відповідно до типів використовуваних в них знаків Є. Я. Басін поділяє на три групи: образотворчі (живопис, скульптура), словесні (художня література), виражальні (музика, танець) [1].

Слід зауважити, що знак-образ мав велике практичне значення вже на ранніх стадіях філогенетичного розвитку людства. Як свідчать археологічні дослідження, перші рухові знаки з'явилися ще в доісторичні часи: людина малювала на стінах свого житла епізоди полювання і танців, які в майбутньому стали дослідникам за першоджерела про виникнення жестикуляції [16]. За словами італійського вченого-просвітителя Дж. Віко, в далекій давнині люди використовували для комунікації жести, які були ні чим іншим, як образними знаками $[15,93]$. Згодом у процесі реконструкції архаїчних культур виникла гіпотеза про давню мову жестів, названу М. Я. Марром «яфетичною» (від імені одного з синів Ноя - Яфета, Іафета) мовою [22]. Відповідно до цієї гіпотези, в архаїчних культурах звукові передують суто мімічні або пантомімічні рухи, в яких виражаються певні емоційні стани, і тому найдавнішою мовою $є$ мова жестів-знаків-покажчиків і мова образотворчих знаків-символів. Оскільки цій жестовій комунікації відповідає домовленевий інтелект, західний вчений А. Меррей відводив первісному танцю роль виразника емоцій, замінника ще не народженої мови [23]. Організована ритмом пластика людського тіла в давнину мала переважне значення в культових дійствах; слово ж як початок, який формує свідомість, проявилося в пізніші часи.

Як відомо, архаїчне мислення вирізнялося високою мірою емоційності й наочно-образним характером. Причини переходу від архаїчного мислення до абстрактно-логічного багато в чому так і залишаються для науки таємницею. Тим часом недостатньо уваги приділяється в цьому найважливішому процесі ролі первісного мистецтва, пер- шим витком діалектичного розвитку якого стало, на переконання В. С. Сжова, естетичне почуття первісної людини [8]. Емоційність і високий рівень образності архаїчного мислення обумовили появу символів. Звернення до них можна вважати спробою перейти від світу сприйняттів до системи умовиводів. Однак поява і функціонування символів вимагали певної мотивації, і найважливішою серед них стала потреба в спілкуванні як необхідна умова, з одного боку, стабільного існування соціальної спільності, а з іншого - існування здатного до рефлексії індивіда.

Підвищена емоційність сприйняття при недостатньому «лексичному запасі» первісної людини викликала проблеми в спілкуванні. Обсяг інформації тим часом постійно збільшувався, і для його передання були потрібні специфічні форми існування i «руху» символів, які б забезпечили особисте, тісне спілкування і були б органічними щодо інтегративної природи людини, тобто відповідали б іiі прагненню до цілісності, об'єднання, єдності. Такою формою став танець, який можна розглядати які систему символів. На ранньому етапі розвитку людства саме різноманітні рухи, танець становили основу, з одного боку, індивідуального самовираження, а з іншого - фундамент сигнальної протокомунікації, протоспілкування між людьми. Звідси стає зрозумілим те величезне значення, яке у багатьох сучасних народів, що перебувають в умовах традиційного суспільства, має феномен танцю.

Отже, саме символізм виступає вищим виявом образного танцювального мистецтва. Танець, що включає ірраціональний початок, $є$ символічним, він відтворює явища зовнішнього світу 3 допомогою символів. У цьому його органічний зв'язок 3 усім світом культури: як відзначав Ю. М. Лотман, культура має символічну природу і завжди $\epsilon$ сферою символізму, символіки [10]. Оскільки культура має на увазі збереження попереднього досвіду, то вона являє собою в тому числі і певну кількість успадкованих символів. Жодна культура і жодне мистецтво неможливі без них: «Будь-яке мистецтво символічне - сьогодення, минуле, майбутнє», проголосив А. Бєлий [4]. Символ, на переконання А. Бєлого, це образ, взятий з природи, і перетворений творчістю, тому твір мистецтва $\epsilon$ символічним за своєю суттю. В кінцевому рахунку мистецтво транслює ту чи іншу модель культурного буття, закріплюючи іiї в символах-узагальненнях і символах-нормативах. У мистецтві створюються символи буття, а не саме буття чи реальність, і в цьому сенсі символізм притаманний будь-якому прояву людської творчості [4]. 
Поняття «символ» $є$ одним 3 найбільш багатозначних у системі семіотичних наук. «Найбільш звичне уявлення про символ пов'язане з ідеєю деякого змісту, яке, в свою чергу, слугує планом вираження для іншого, як правило, культурно більш цінного змісту», — зауважував Ю. М. Лотман [10]. На відміну від знака, який має лише одне значення, символ $є$ складнішим, його багатозначність не можна дешифрувати зусиллям розуму. Символ відрізняється від простого знака тим, що якщо для знакової системи багатозначність є лише перешкодою, котра шкодить раціональному функціонуванню, то символ тим змістовніший, чим більш він багатозначніший. Суть символу буде втрачена, якщо надати йому те чи інше кінцеве тлумачення, оскільки «ємність», таємниця символу виникає 3 його смислової невичерпності. Тому символ розглядається як найбільш ємний засіб фіксації загальнолюдського досвіду, а символічна мова - як мова цілісного світогляду. У зв'язку з цим світ у танці отримує своє цілісне відображення.

Оскільки символ має здатність зберігати в згорнутому вигляді виключно великі та значні тексти, то в мистецтві образ завжди висловлює ще щось понад те значення, безпосереднім вираженням якого він $€$. Подібне значення символу в мистецтві відзначав ще Й. В. Гете: «Символіка перетворює явище на ідею, ідею на картину, але так, що ідея в картині завжди залишається такою, котра нескінченно впливає, і недосяжною, і навіть будучи виражена всіма мовами, все ж залишається несказанною» [7]. На думку ж американського філософа свідомості й естетики С. Лангера, «символ — будь-який засіб, з допомогою якого ми здатні здійснити абстракцію» [1], що його дослідниця називає головним серед трансформаційних процесів.

Символи культури рідко виникають і належать якомусь одному синхронізованому зрізу культури. Як правило, вони пронизують цей зріз по вертикалі, «приходять» 3 глибини століть i, видозмінюючи своє значення, передаються майбутнім станам культури. «Живий символ мистецтва, пронесений історією крізь століття, переломлює в собі різноманітні думки, різноманітні ідеї. Він - потенціал цілої серії ідей, почуттів, хвилювань» [3], — саме так будь-який танець являє собою цілу парадигму певних ідей, норм, поглядів і відносин, що зародилися колись і мали місце протягом усього культурного буття людини. Тому танець має відношення не лише до сучасності, а й до минулого, і до майбутнього.

Перетворення символічних кодів відбувається значно повільніше, ніж, наприклад, соціальної сфери культури, тому символи є одним з найбільш стійких елементів культурного простору. Танець у зв'язку з цим виступає в ролі хранителя тієї культурно значущої інформації, яка сягає своїм корінням у глибину століть, і в наступні епохи виступає як символи. Будучи важливим механізмом пам'яті культури, символи переносять тексти, сюжетні схеми, норми та інші семіотичні утворення з одного культурного прошарку в іншій. В цьому відношенні «константні набори символів, які пронизують діахронію культури, значною мірою беруть на себе функцію механізмів єдності: здійснюючи пам'ять культури про себе, вони не дають їй розпастися на ізольовані хронологічні пласти» [10]. Структура символу спрямована на те, щоб занурити кожен артефакт у цілісний образ культури, тому танець, несучи в собі певний набір символів, виступає як механізм культурної пам'яті, як механізм успадкування.

Таким чином, знаковий, комунікативний характер притаманний танцювальним рухам від початку, а отже мовний аспект розгляду танцювальних рухів вимагає їх визначення як знаків, а танцю - як знакової системи. Для розгляду танцювального мистецтва як знакової системи i, отже, як специфічної мови, потрібно передусім досліджувати особливості його участі в процесі семіозису — процесу, в якому щось функціонує як знак. Цей процес у традиції, висхідній до греків, зазвичай розглядався як такий, що включає три (або чотири) чинники: те, що виступає як знак; те, на що вказує (refers to) знак; вплив, через який відповідна річ виявляється для інтерпретатора знаком. Ці три компоненти семіозису Ч. У. Морріс називає відповідно знаковим засобом (або знаконосієм) (sign vehicle), десигнатом, (designatum) й інтерпретантою (interpretant), а в якості четвертого чинника вводить поняття інтерпретатора (interpreter) [13]. Дослідник відзначає: «терміни “знак”, “десигнат”, “інтерпретанта” й “інтерпретатор" мають на увазі один одного, оскільки це просто способи вказування на аспекти процесу семіозису. Зовсім не обов' язково, щоб на об'єкти вказувалося з допомогою знаків, але, якщо немає такої референції, немає і десигната; щось $є$ знаком лише тому, що воно інтерпретується як знак чогось деяким інтерпретатором; [узагальнене] врахування чогось $€$ інтерпретантою лише настільки, наскільки воно викликається чимось, що функціонує як знак; деякий об'єкт є інтерпретатором лише тому, що він опосередковано враховує щось. Властивості знака, десигната, інтерпретатора або інтерпретанти — це властивості реляцій- 
ні, набуті об'єктами в функціональному процесі семіозису» [13]. Таким чином знаком у мистецтві танцю $є$ зрима форма танцювального руху, а також танцівники, які беруть безпосередню участь у виконанні. Враховуючи також те, що основним «матеріалом» хореографічного мистецтва $\epsilon$ людське тіло, що виражає певну духовну інформацію, можна констатувати, що знак у танці являє собою складне духовно-матеріальне утворення.

Отже, застосування до танцювального мистецтва методології процесу семіозису дає можливість відкрити об'єктивні інформаційні комунікативні властивості рухів танцю і виявити в них якості специфічної мови. При цьому символ у танцювальному мистецтві «виступає ніби конденсатором всіх принципів знаковості і одночасно виводить за межі знаковості» [10]. Так, знаковість, образність, символізм $є$ основою мовною природою танцю і дають йому можливість поєднувати між собою знаки різних рядів і мов. У зв'язку з цим правомірно говорити про властиву хореографічному мистецтву здатність зберігати і транслювати в «згорнутому» вигляді виключно великі і значущі культурні тексти.

У подальшому грунтовного дослідження потребує виявлення в природі танцю мовних (інформаційно-комунікативних) властивостей та їхньої невербальної специфіки, а також дослідження особливостей процесу комунікації в танці.

\section{Джерела та література}

1. Басин Е. Я.Семантическая философия искусства / Е. Я. Басин [Электр. ресурс]. — Режим доступа : basin-e. narod.ru/Semantica.doc. - Название с экрана.

2. Басин Е. Я.Семиотика об изобразительности и выразительности / Е. Я. Басин. - Москва : Искусство, 1965. $234 \mathrm{c}$.

3. Белый А. Смысл искусства / А. Белый [Электр. ресурс]. Режим доступа : http://az.lib.ru/b/belyj_a/text_05_1904_ simvolizm.shtml. - Название с экрана.

4. Белый А. Эмблематика смысла / А. Белый [Электр. ресурс]. - Режим доступа : http://az.lib.ru/b/belyj_a/ text_05_1904_simvolizm.shtml. — Название с экрана.

5. Быховская И. М. Телесность человека как объект социокультурного анализа : автореф. дис. на соиск. науч. степени д-ра филос. наук : 17.00.08 / И. М. Быховская. - [б.м.], 1992. - $295 \mathrm{c}$.

6. Гевленко Ю. А. Семиотический анализ танца / Ю. А. Гевленко [Электр. pесурс]. - Режим доступа : http:// cyberleninka.ru/article/n/semioticheskiy-analiz-tantsa. Название с экрана.

7. Гете И. В. Об искусстве / И. В. Гете [Электр. ресурс]. Режим доступа : http://royallib.com/read/gete_iogann/ob_ iskusstve_sbornik_statey.html\#0. - Название с экрана.

8. Ежов В. С. К решению проблемы генезиса эстетического сознания древнего человека / В. С. Ежов [Электр. ресурс]. - Режим доступа : http://www.sati.archaeology.nsc. ru/Home/pub/Data/?html=gn6.htm\&id=361. - Название с экрана.
9. Леонова С. Є. Символіка тілесності у сучасній театральній хореографії (на прикладі М. Ека) [Електр. ресурс]. Режим доступу : file://C:/Users/Admin/Downloads/ VKhITK_2011_958(1)_44_6.pdf. — Назва з екрана.

10. Лотман Ю. М. Символ в системе культуры / Ю. М. Лотман [Электр. ресурс]. - Режим доступа : http://www. philology.ru/literature1/lotman-92e.htm. - Название с экрана.

11. Матвейчук М. До проблеми тілесності в сучасному танці / М. Матвейчук [Електр. ресурс]. - Режим доступу : http://sm.etnolog.org.ua/zmist/2015/1/64.pdf. — Назва 3 екрана.

12. Мерло-Понти М. Феноменология восприятия (1945) / М. Мерло-Понти ; пер. с фр. ; [под ред. И. С. Вдовиной, С. Л. Фокина]. - Санкт-Петербург : Ювента ; Наука, 1999. - $603 \mathrm{c}$.

13. Моррис Ч. У. Основания теории знаков / Чарльз Уильям Моррис [Электр. pecypc]. - Режим доступа : http://www. bim-bad.ru/docs/morris_semiotics.pdf. - Название с экрана.

14. Мосс М. Техники тела / М. Мосс // Мосс М. Общества. Обмен. Личность : тр. по социальной антропологии : пер. с франц. - Москва : Вост. литература, 1996. - С. 242263.

15. Романовская Е. В. История, память и традиция в культурологии Дж. Вико / Е. В. Романовская // Фундаментальные проблемы культурологии : сб. ст. по материалам конгресса / отв. ред. Д. Л. Спивак. - Москва : Новый хронограф : Эйдос. - Т. 6 : Культурное наследие: От прошлого к будущему. - 2009. - С. 92-104.

16. Ромм В. В.Танец как фактор эволюции человеческой культуры : автореф. дис. на соиск. науч. степени д-ра культур. : 24.00.01 / В. В. Ромм. — Барнаул, 2006 [Электр. peсурс]. - Режим доступа : http://www.dissercat. $\mathrm{com} /$ content/tanets-kak-faktor-evolyutsii-chelovecheskoikultury. - Название с экрана.

17. Соломоник А.Философия знаковых систем и язык / А. Соломоник. - Минск : «МЕT», 2002. - 362 с.

18. Станишевский Ю. Украинский балетный театр: история и современность / Юрий Станишевский. - Київ : Муз. Україна, 2008. - $411 \mathrm{c}$.

19. Цветкова Л. Ю. Методика викладання класичного танцю : підруч. / Л. Ю. Цветкова. — 2-е вид. - Київ : Альтерпрес, 2007. - $324 \mathrm{c}$.

20. Чілікіна Н.Сучасні аспекти філософії тілесності як ключ до мови тіла [Електр. ресурс]. - Режим доступу : http://publications.lnu.edu.ua/bulletins/index.php/artstudies/ article/viewFile/3066/3129. - Назва з екрана.

21. Чурпіта Т. М. Професійне становлення М. Трегубова (1928-1935 pp.) / Т. М. Чурпіта // Мистецтвознавчі записки. - 2014. - Вип. 26. - С. 302-309.

22. Шилков Ю. М. Яфетическая философия языка Н. Я. Марpa / Ю. М. Шилков [Электр. ресурс]. — Режим доступа : http://philosophy.spbu.ru/userfiles/rusphil/Veche\%20 \%Е2\%84\%9616-6.pdf. - Название с экрана.

23. Шкурко Т. А. Танцевально-экспрессивный тренинг / T. А. Шкурко [Электр. pесурс]. — Режим доступа :https:// www.psyoffice.ru/page, 8,3414-shkurko-t.-a.-tancevalnojekspressivnyjj-trening..html. - Название с экрана.

\section{References}

1. Basin, E. Ya. Semanticheskaya filosofiya iskusstva / E. Ya. Basin. - Retrieved from: basin-e.narod.ru/Semantica. doc. - Nazvanie s ekrana.

2. Basin, E. Ya. Semiotika ob izobrazitelnosti i vyirazitelnosti / E. Ya. Basin. - Moskva : Iskusstvo, 1965. - $234 \mathrm{~s}$.

3. Belyiy, A. Smyisl iskusstva / A. Belyiy. - Retrieved from: http://az.lib.ru/b/belyj_a/text_05_1904_simvolizm.shtml. Nazvanie s ekrana. 
4. Belyiy,

A. Emblematika

smyisla A. Belyiy. - Retrieved from: http://az.lib.ru/b/ belyj_a/text_05_1904_simvolizm.shtml. — Nazvanie s ekrana.

5. Byihovskaya, I. M. Telesnost cheloveka kak ob'ekt sotsiokulturnogo analiza : avtoref. dis. na soisk. nauch. stepeni d-ra filos. nauk : 17.00.08 / I. M. Byihovskaya. [b.m.], 1992. - $295 \mathrm{~s}$.

6. Gevlenko, Yu. A. Semioticheskiy analiz tantsa / Yu. A. Gevlenko. - Retrieved from: http://cyberleninka. $\mathrm{ru} /$ article/n/semioticheskiy-analiz-tantsa. - Nazvanie s ekrana.

7. Gete, I. V. Ob iskusstve / I. V. Gete. - Retrieved from: http:// royallib.com/read/gete_iogann/ob_iskusstve_sbornik_statey. html\#0. - Nazvanie s ekrana.

8. Ezhov, V. S. K resheniyu problemyi genezisa esteticheskogo soznaniya drevnego cheloveka / V.S. Ezhov. - Retrieved from: http://www.sati.archaeology.nsc.ru/Home/pub/ Data/?html=gn6.htm\&id=361. - Nazvanie s ekrana.

9. Leonova, S. Ye. Symvolika tilesnosti u suchasnii teatralnii khoreohrafii(na prykladi M. Eka). — Retrieved from: file:///C:/ Users/Admin/Downloads/VKhITK_2011_958(1)_44_6. pdf. - Nazva z ekrana.

10. Lotman Yu. M. Simvol v sisteme kulturyi / Yu. M. Lotman. Retrieved from: http://www.philology.ru/literature1/lotman92e.htm. - Nazvanie s ekrana.

11. Matveichuk, M.Do problemy tilesnosti v suchasnomu tantsi / M. Matveichuk. - Retrieved from: http:// sm.etnolog.org.ua/zmist/2015/1/64.pdf. - Nazva z ekrana.

12. Merlo-Ponti, M. Fenomenologiya vospriyatiya (1945) / M. Merlo-Ponti ; per. s fr. ; [pod red. I. S. Vdovinoy, S. L. Fokina]. — Sankt-Peterburg : Yuventa ; Nauka, 1999. $603 \mathrm{c}$.

13. Morris Ch. U. Osnovaniya teorii znakov / Charlz Uilyam Morris. - Retrieved from: http://www.bim-bad.ru/docs/ morris_semiotics.pdf. — Nazvanie s ekrana.
14. Moss, M. Tehniki tela / M. Moss // Moss M. Obschestva. Obmen. Lichnost : tr. po sotsialnoy antropologii : per. $\mathrm{s}$ frants. - Moskva : Vost. literatura, 1996. - S. 242-263.

15. Romanovskaya, E. V. Istoriya, pamyat itraditsiya vkulturologii Dzh. Viko / E.V. Romanovskaya // Fundamentalnyie problemyi kulturologii : sb. st. po materialam kongressa / otv. red. D. L. Spivak. - Moskva : Novyiy hronograf : Eydos. T. 6 : Kulturnoe nasledie: Ot proshlogo $\mathrm{k}$ buduschemu. 2009. - S. 92-104.

16. Romm, V.V.Tanets kak faktor evolyutsii chelovecheskoy kulturyi : avtoref. dis. na soisk. nauch. stepeni d-ra kultur. : 24.00.01 / V.V.Romm. - Barnaul, 2006. - Retrieved from: http://www.dissercat.com/content/tanets-kak-faktorevolyutsii-chelovecheskoi-kultury. - Nazvanie s ekrana.

17. Solomonik, A. Filosofiya znakovyih sistem i yazyik / A. Solomonik. - Minsk : «MET», 2002. - 362 s.

18. Stanishevskiy, Yu. Ukrainskiy baletnyiy teatr: istoriya i sovremennost / Yuriy Stanishevskiy. - Kyiv : Muz. Ukrayina, 2008. - $411 \mathrm{~s}$.

19. Tsvetkova, L. Yu. Metodyka vykladannia klasychnoho tantsiu : pidruch. / L. Yu. Tsvetkova. - 2-e vyd. - Kyiv : Alterpres, 2007. - $324 \mathrm{~s}$.

20. Chilikina, N. Suchasni aspekty filosofii tilesnosti yak kliuch do movy tila. - Retrieved from: http://publications. lnu.edu.ua/bulletins/index.php/artstudies/article/ viewFile/3066/3129. — Nazva z ekrana.

21. Churpita, T. M. Profesiine stanovlennia M. Trehubova (19281935 rr.) / T. M. Churpita // Mystetstvoznavchi zapysky. 2014. - Vyp. 26. - S. 302-309.

22. Shilkov, Yu. M. Yafeticheskaya filosofiya yazyika N.Ya. Marra / Yu. M. Shilkov. — Retrieved from: http://philosophy. spbu.ru/userfiles/rusphil/Veche \#16-6.pdf. - Nazvanie s ekrana.

23. Shkurko, T.A. Tantsevalno-ekspressivnyiy trening / T.A. Shkurko. - Retrieved from: https://www.psyoffice. ru/page, 8,3414-shkurko-t.-a.-tancevalno-jekspressivnyjjtrening..html. - Nazvanie s ekrana. 